\title{
Modifications AISi9CuMnNi Alloy by Antimony and Heat Treatment and Their Influence on the Resulting Structure
}

Natasa Naprstkova, Radek Cervinka, Sylvia Kusmierczak, Jaromir Cais

Faculty of Production Technology and Management, J. E. Purkyne University in Usti nad Labem. Pasteurova 1, 40096 Usti nad Labem. Czech Republic. E-mail: naprstkova@fvtm.ujep.cz; cervinka@fvtm.ujep.cz; kusmierczak@fvtm.ujep.cz, cais@fvtm.ujep.cz

Modification alloy is an important part of the metallurgical process, and this also applies, of course, for aluminum alloys, particularly for Al-Si (silumins). As a modification of the material we can use the modification using the selected element or heat treatment of alloys, or a combination of both processes. One of the elements that it is possible to modify the alloy of Al-Si used is antimony $(\mathrm{Sb})$. The paper examines the possible effect of the modification that element and heat treatment on the final structure of the alloy AISi9CuMnNi. In the experiments were made three castings from the alloy AISi9CuMnNi without modification, three castings with the modification and without heat treatment, three castings with modification and without heat treatment, and three castings with modification and heat treatment too. The described experiment and analysis are part of extensive research, focusing on a Faculty of Production Technology and Management, J. E. Purkyne University in Usti nad Labem.

Keywords: alloy, aluminum, modifications, antimony structure, heat treatment

\section{Acknowledgement}

Authors are grateful for the support of grant SGS 2014 UJEP and of grant OP 2.2 No. CZ.1.07/2.2.00/28.0296.

\section{References}

[1] BOLIBRUCHOVA, D., TILLOVA, E. (2005). Zlievarenské zliatiny Al-Si. ŽU v Žiline, EDIS, ISBN 80-8070485-6

[2] MICHNA, S., LUKAC, I., OCENASEK, V., KORENY, R., DRAPALA, J., SCHNEIDER, H., MISKUFOVA, A. and coll. (2005) Encyklopedie hliníku. Adin, Prešov, ISBN 80-89041-88-4.

[3] MICHNA, S., KUSMIERCZAK, S. (2008). Technologie a zpracovani hlinikovych materialu, UJEP. Usti nad Labem, ISBN 978-80-7044-998-1.

[4] WEISS, V. (2012). Prodloužení modifikačního účinku pomoci beryllia u slitin AlSi7Mg0,3. In: Slévárenství, No. 5-6, ISSN 0037-825

[5] WEISS, V. (2012). Hodnoceni vlivu teploty a doby homogenizačniho žíhání slitiny AlCu4MgMnz hlediska mikrostruktury, obrazové analýzy a metody EDX, In: Strojírenská technologie. Vol. 17, No. 5,6, , p. 348-355, ISSN 1211-4162

[6] MICHNA, S., NOVA, I. (2008). Technologie a zpracování kovových materialu. Adin, s.r.o.,Prešov, ISBN 97880-89244-38-6

[7] ROUCKA, J. (2004). Metalurgie neželezných slitin. Brno, CERM, 148 p. ISBN 80-214-2790-6

[8] MICHNA, S. NAPRSTKOVA, N. (2011). The Mechanical Properties Optimizing of of Al - Si Alloys Precipitation Hardening and the Effect on the Character of the Chip. In Acta Metallurgica Slovaca, No. 3, ISSN 1335-1532

[9] TILlOVA, E., FARKASOVA, M., CHALUPOVA, M. (2013) The Role of Antimony in Modifying of Al-Si-Cu Cast Aloy. In Manufacturing Technology, Vol. 13, No. 1, pp. 109-114, ISSN 1213-2489

[10]ČSN EN 1796 Hlinik a slitiny hliniku - Odlitky - Chemicke slozeni a mechanicke vlastnosti

[11]KALINCOVA, D. (2010). Skúšanie mechanických vlastností materiálov - prehl’ad meracích metód a zariadení. In proceedings Zvyšovanie efektívnosti vzdelávacieho procesu prostredníctvom inovačných prostriedkov, KEGA 3/6370/08., TU vo Zvolene, Zvolen, pp. 13-26.

[12]LIPINSKI T. (2011). Microstructure and Mechanical Properties of the AlSi13Mg1CuNi Alloy with Ecological Modifier. Manufacturing Technology. 2011, Vol. 11, pp 40-44.

[13]TILlova, E., CHAlupova, M., HURTAlOVA, L., DURINIKOVA, E. (2011). Quality Control of Microstructure in Recycled Al-Si Cast Alloys. In Manufacturing Technology, Vol.11, No.11, pp. 70-76. ISBN 1213-2489

[14]MICHALCOVA, A., VOJTECH, D. (2012). Structure of rapidly solidified aluminium alloys. In Manufacturing Technology, Vol.12, No.13, pp. 166-169, ISSN1213-24891 